W. J. YE ${ }^{1}$ and Sh. Q. LIU ${ }^{1}$

\title{
ROLES OF CELL COMPARTMENTS IN THE VARIATION OF FIRING PATTERNS GENERATED BY REDUCED PACEMAKER MODELS OF THE CRUSTACEAN STOMATOGASTRIC GANGLION
}

\begin{abstract}
Received June 18, 2014
Endogenous bursters in central pattern generators (CPGs) generate rhythmic firing patterns controlling regular movements in the organism. Based on a pacemaker kernel model of the stomatogastric ganglion (SGG) of crustaceans, we constructed three reduced models, (i) dendrite-reduced model (DRM), (ii) axon-reduced model (ARM), and (iii) primary neuritereduced model (PNRM). Similar firing patterns were observed in two models except the axonreduced one. Perturbing of various parameters in the models induced bifurcation phenomena in the occurrence of interspike intervals (ISIs), which depicted variation of the firing patterns. By comparing and analyzing two-dimensional parameter planes derived from the above different models, the effects of compartments on varying firing patterns were detected. In particular, a different kind of period-doubling transition mode of firing patterns, which varied via a ring-shape mode, was found.
\end{abstract}

Keywords: endogenous bursters, central pattern generator, interspike intervals, pacemaker kernel model, reduced model, cell compartments.

\section{INTRODUCTION}

Endogenously bursting neurons play an important role in generating rhythmic patterned outputs of central pattern generators (CPGs) [1-6]. This kind of neurons has been discovered in a great number of organisms. The R15 neuron in Aplysia and the pacemaker kernel of the pyloric circuit of the stomatogastric ganglion (SGG) in crustaceans can serve as examples of such generators $[7,8]$.

Endogenous bursters in crustaceans show at least two kinds of firing patterns; these are a tonic spiking pattern and a bursting pattern [9]. Major attention in a number of studies has been focused on the mechanism by which firing patterns vary between the regular spiking and bursting modes; the respective shifts are related to the corresponding changes in the behavioral patterns [10]. This mechanism appeared to be influenced by some ion channels, in including sodium, calcium, and potassium ones; activation or blocking of these channels experimentally makes the

\footnotetext{
${ }^{1}$ School of Mathematics, South China University of Technology, Guangzhou, China.

Correspondence should be addressed to: Sh. Q. Liu

(e-mail: mashqliu@scut.edu.cn).
}

neurons to exhibit different firing patterns in an SGG anterior burster neuron $[11,12]$. Actually, the shape of bursts may change as a result of alteration of the parameters of ion channels, such as the conductance and equilibrium potential. Golowasch et al. [13] compared the model and biological neurons, in order to study the contribution of ion channels to the firing patterns. As a result, the authors found that variation of a few conductances induces a lateral pyloric neuron to move from one mode to another by perturbing the parameters in the examined cell unit. Furthermore, regulation of the synaptic strength can also induce different dynamic responses and alter the intrinsic period of fluctuation of the membrane potential. A phase response curve (PRC) was used to characterize the variation of the firing mode after applying inhibitory and excitatory synaptic conductance pulses $[14,15]$.

In order to understand the role of the cell compartments in varying the firing patterns, we constructed three reduced models based on the pacemaker kernel model proposed by Maran et al. [15]. In these compartmental models, we treated the compartment as a whole to find some common characters, no matter what ion channels it had. The index of interspike intervals (ISIs) was utilized to 
describe variations of the firing patterns. In some experimental results, variations of ISIs have been found to be a good match with the modeling results [16-18]. Thus, comparison of ISI bifurcation diagrams between the derived models and the original model will provide insight into the mechanism responsible for the variation of firing patterns. In addition, the spikecounting method has been used to detect distributions of the firing patterns within a two-dimensional parameter plane $[19,20]$. A comparison of these planes will provide a comprehensive way to understand the effect of compartments on the transition modes of the firing patterns.

\section{DESCRIPTION OF THE COMPARTMENTAL MODELS}

Based on the model introduced by Maran et al. [15], we constructed three reduced models by removing different cell compartments. As the dendrite has been removed, we refer this reduced model as a "dendritereduced model" (DRM). Similarly, the other two reduced models were named a "primary neurite- reduced model" (PNRM) and an "axon-reduced model (ARM) (Fig. 1).

The intact model is described by the following Hodgkin-Huxley-type equations.

$$
\begin{aligned}
& C_{m, s} d V_{s} / d t=-\left(I_{\text {leak }}+G_{s p n}\left(V_{s}-V_{p n}\right)\right) \\
& \begin{array}{c}
C_{m, p n} d V_{p n} / d t=-\left(I_{K s}+I_{l e a k}+G_{s p n}\left(V_{p n}-V_{s}\right)+G_{d p n}\left(V_{p n}-\right.\right. \\
\left.\left.\quad-V_{d}^{d}\right)+G_{a p n}\left(V_{p n}-V_{a}\right)\right)
\end{array} \\
& C_{m, d} d V_{d} / d t=-\left(I_{K C a}+I_{C a}+I_{A}+I_{K f}+I_{\text {leak }}+G_{d p n}\left(V_{d}-V_{p n}\right)\right) \\
& C_{m, a} d V_{a} / d t=I_{e x t}-\left(I_{N a}+I_{K d r}+I_{\text {leak }}+G_{d p n}\left(V_{a}-V_{p n}\right)\right)
\end{aligned}
$$

Here, $V_{s}, V_{p n}, V_{d}$, and $V_{a}$ represent the membrane potentials in the soma, primary neurite, dendrite, and axon, respectively. The currents through each ion channel follow the equations presented below.

$$
\begin{aligned}
I_{N a} & =g_{n a} m^{3} h\left(V-E_{n a}\right), d m / d t=a_{m}(1-m)-b_{m} m, d h / d t= \\
& =0.8 a_{h}(1-h)-b_{h} h \\
a_{m} & =(0.121 V+2.871) /(1-\exp (-0.121 V-2.871)), \\
b_{m} & =4 \exp (-2.984-0.0672 \mathrm{~V}) \\
a_{h}= & 0.07 \exp (-2.686-0.0605 \mathrm{~V}), \\
b_{h}= & 1 /(1+\exp (-2.371-0.121 \mathrm{~V}))
\end{aligned}
$$

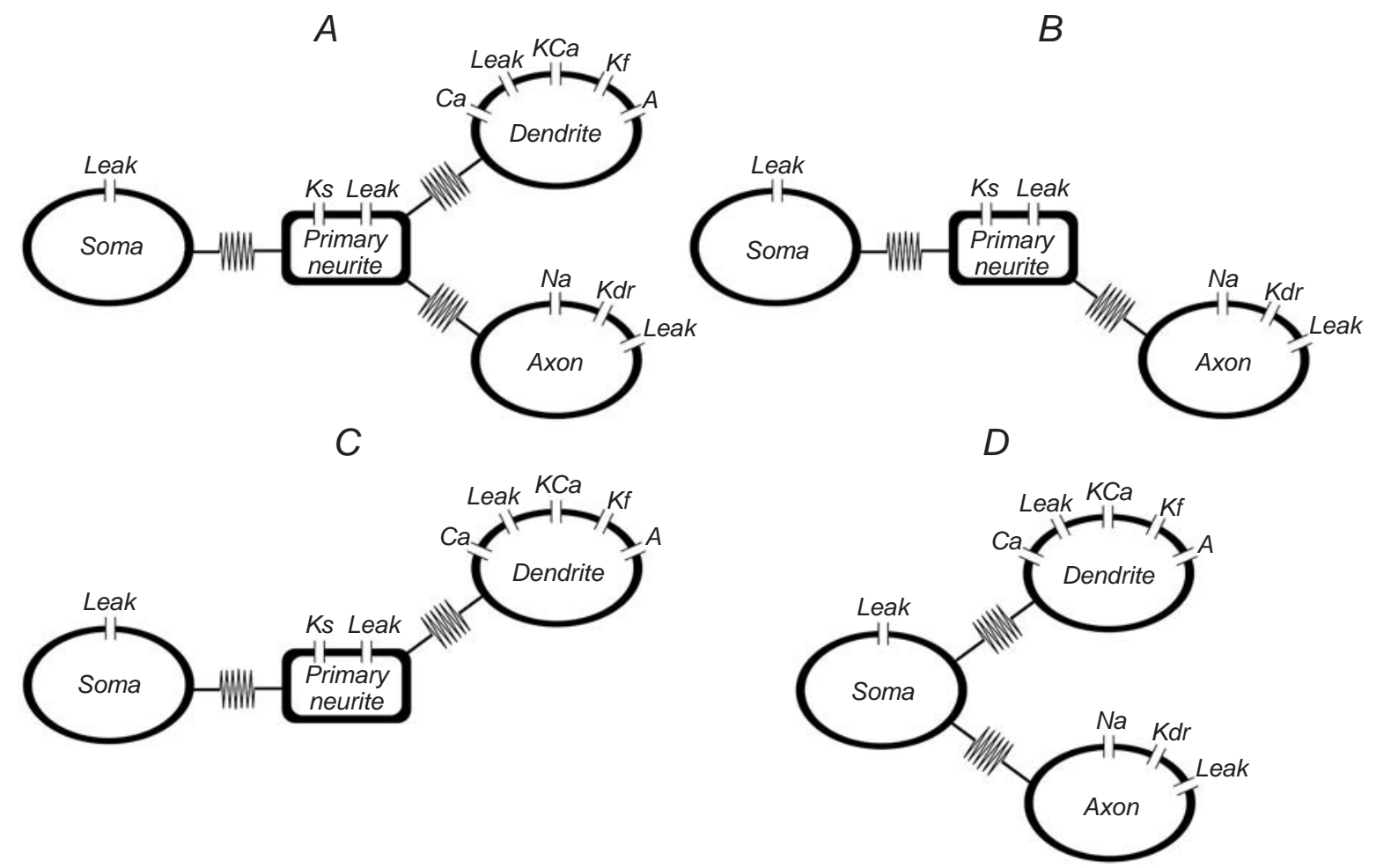

F i g. 1. Structure and ion channels of the intact model (A) and three reduced models (B-D).

Р и с. 1. Структура інтактної моделі (А) та трьох редукованих моделей (B-D), а також присутні в них іонні канали. 
T a b l e 1. Parameters in the Models

Т а б л и ц я П. Параметри моделей

\begin{tabular}{c|ccc|c|c|c|c|c|c|c}
\hline Parameter & Value & Parameter & Value & Parameter & Value & Parameter & Value & Parameter & Value \\
\hline$I_{e x \mathrm{t}}(\mathrm{nA})$ & 0.2 & $c\left(\mathrm{msec}^{-1}\right)$ & 0.0016 & $s_{\mathrm{a}}(\mathrm{mV})$ & -26 & $\mathrm{~g}_{N a}(\mu \mathrm{S})$ & 15.0 & $\mathrm{G}_{s p n}(\mu \mathrm{S})$ & 0.05 \\
$\mathrm{E}_{N a}(\mathrm{mV})$ & 30 & $\mathrm{~K}_{A}\left(\mathrm{msec}^{-1}\right)$ & 1 & $s_{\mathrm{b}}(\mathrm{mV})$ & 6 & $\mathrm{~g}_{C a}(\mu \mathrm{S})$ & 0.04 & $\mathrm{G}_{a p n}(\mu \mathrm{S})$ & 0.5 \\
$\mathrm{E}_{C a}(\mathrm{mV})$ & 140 & $\phi_{\mathrm{z}}(\mathrm{msec})$ & 23 & $\mathrm{~g}_{L, d}(\mu \mathrm{S})$ & 0.0334 & $\mathrm{~g}_{K s}(\mu \mathrm{S})$ & 0.065 & $\mathrm{G}_{d p n}(\mu \mathrm{S})$ & 0.04 \\
$\mathrm{E}_{K}(\mathrm{mV})$ & -75 & $\phi_{\mathrm{b}}(\mathrm{msec})$ & 1 & $\mathrm{~g}_{L, p n}(\mu \mathrm{S})$ & 0.001 & $\mathrm{~g}_{K f}(\mu \mathrm{S})$ & 0.07 & $\mathrm{G}_{s d}(\mu \mathrm{S})$ & 0.2 \\
$\mathrm{E}_{L}(\mathrm{mV})$ & -40 & $z_{\mathrm{b}}(\mathrm{mV})$ & -50 & $\mathrm{~g}_{L, d}(\mu \mathrm{S})$ & 0.001 & $\mathrm{~g}_{K C a}(\mu \mathrm{S})$ & 0.273 & $\mathrm{G}_{s a}(\mu \mathrm{S})$ & 0.8 \\
$\pi_{\mathrm{n}}\left(\mathrm{msec}^{-1}\right)$ & 0.8 & $v_{\mathrm{a}}(\mathrm{mV})$ & -12 & $\mathrm{~g}_{L, d}(\mu \mathrm{S})$ & 0.001 & $\mathrm{~g}_{A}(\mu \mathrm{S})$ & 100 & $C_{m}(\mathrm{nF})$ & 1.0 & \\
$\pi_{\mathrm{h}}\left(\mathrm{msec}^{-1}\right)$ & 0.8 & $v_{\mathrm{b}}(\mathrm{mV})$ & -62 & $\mathrm{~g}_{K d r}(\mu \mathrm{S})$ & 8.0 & & \\
\hline
\end{tabular}

The derived models could be obtained by reducing the corresponding compartment. Most respective parameters are shown in Table 1. The compartmental models are programmed in Python, using a fourthorder Runge-Kutta method. All diagrams are drawn by an open-source library named Matplotlib (Python).

$$
\begin{aligned}
& I_{K d r}=g_{K d r} n^{3}\left(V-E_{K}\right), d n / d t=0.8 a_{n}(1-n)-b_{n} n, b_{n}= \\
& =0.125 \exp (-0.421-0.0151 \mathrm{~V}) \\
& a_{n}=(0.0121 V+0.237) /(1-\exp (-2.429-0.121 V)) \\
& I_{K C a}=g_{K C a}(c /(0.5+c))\left(V-E_{K}\right), d c / d t= \\
& =\rho\left(0.0078 * z\left(E_{C a}-V\right) /(1+2 c)-c\right) \\
& I_{C a}=g_{C a}(z /(0.43+c))\left(V-E_{C a}\right), d z / d t=\left(z_{v}-z\right) / 23 \text {, } \\
& z_{v}=1 /(1+\exp (-0.15(V+50)))
\end{aligned}
$$

$$
\begin{aligned}
I_{A}= & g_{A} m_{A}{ }^{3} h_{A}\left(V-E_{K}\right), m_{A}=1 /(1+\exp (-(V+12) / 26)), \\
& d h_{A} / d t=h_{A i}-h_{A} \\
h_{A i}= & 1 /(1+\exp ((V+62) / 6)) \\
I_{K s}= & g_{K s} p\left(V-E_{K}\right), d p / d t=\left(p_{v}-p\right) / \tau_{p}, p_{v}=1 /(1+ \\
& +\exp (-2(V+45))) \\
\tau_{p}= & 100+3000 /(1+\exp (-(V+50) / 0.05)) \\
I_{K f}= & g_{K f} b\left(V-E_{K}\right), d b / d t=b_{v}-b, b_{v}=1 /(1+ \\
& +\exp (-2(V+42))) \\
I_{\text {Leak }} & =g_{L}\left(V-E_{L}\right)
\end{aligned}
$$

\section{RESULTS}

Comparison of the Firing Patterns and PRC in Different Models. While reducing some compartments

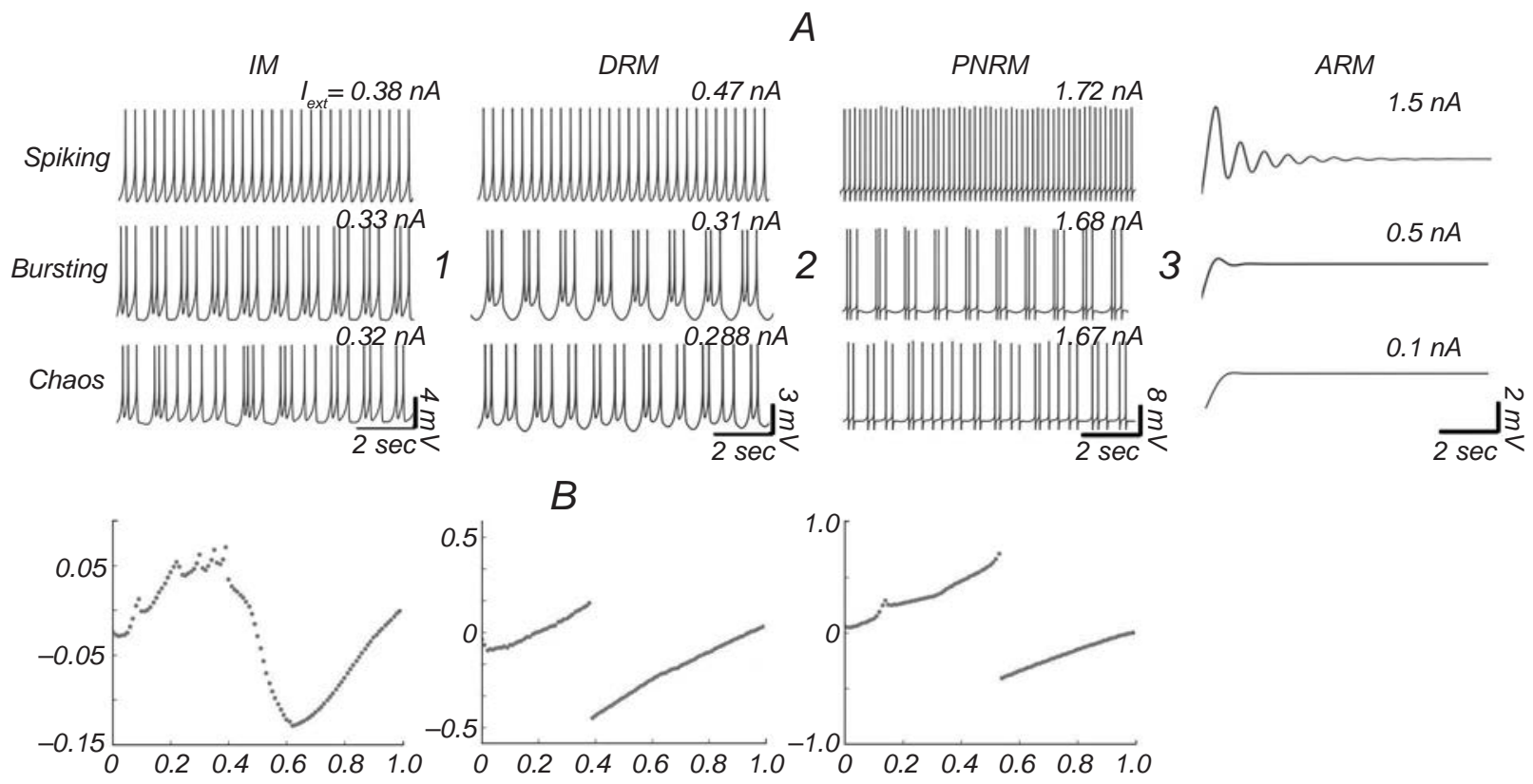

F i g. 2. Comparison of the ISIs bifurcation diagrams among three models.

Р и с. 2. Порівняння діаграм біфуркації міжпікових інтервалів, характерних для трьох моделей. 
from the intact model, the derived models may produce different firing patterns. The response of the reduced models could be studied by applying distinct external stimuli. Figure $3 \mathrm{~A}$ shows the results of such simulations. At a high level of $I_{e x t}$, tonic spiking patterns similar to those in the IM were observed in both DRM and PNRM. However, the ARM responded to the stimulus with seven spikes, which tended to be resting other than a series of spikes. It even maintained the resting pattern as the strength of $I_{e x t}$ decreased, while the other three models demonstrated dynamic responses characterized by bursting and chaotic bursting modes.

Maran et al. [15] reported that there were six kinds of phase-resetting curve (PRC) in the stomatogastric ganglion pacemaker neuron, observed with increases in the synaptic conductance, strength, and duration of the stimuli. In contrast to these curves, however, the PRC in our reduced models only revealed the bilinear mode, no matter what were the magnitude of the synaptic conductance, strength, and duration of the stimulus (Fig. 2B).

Differences of the Transition Modes of Firing Patterns between the Intact Model and Reduced Models. The differences between the intact model and reduced models in the transition modes of firing patterns could provide an insight into the role of model compartments. We use the index of interspike intervals (ISIs) to depict the variation of firing patterns.

Figure 3 illustrates the ISI bifurcation diagrams; ISIs are plotted vs. the $I_{e x t}$, capacitance of the soma $\left(C_{m, s}\right)$, and equilibrium potential of delayed-rectifier potassium channels $E_{K d r}$, respectively. Firstly, we compare the PNRM and IM. When $I_{\text {ext }}$ varied between 1.675 to $1.70 \mathrm{nA}$ in the PNRM, the ISIs demonstrated period-doubling bifurcation, namely bifurcating from one period to four periods. This phenomenon is rather similar to bifurcation modes in the IM when $I_{\text {ext }}$ decreased from 0.40 to $0.37 \mathrm{nA}$. With values smaller than this range, the PNRM, however, does
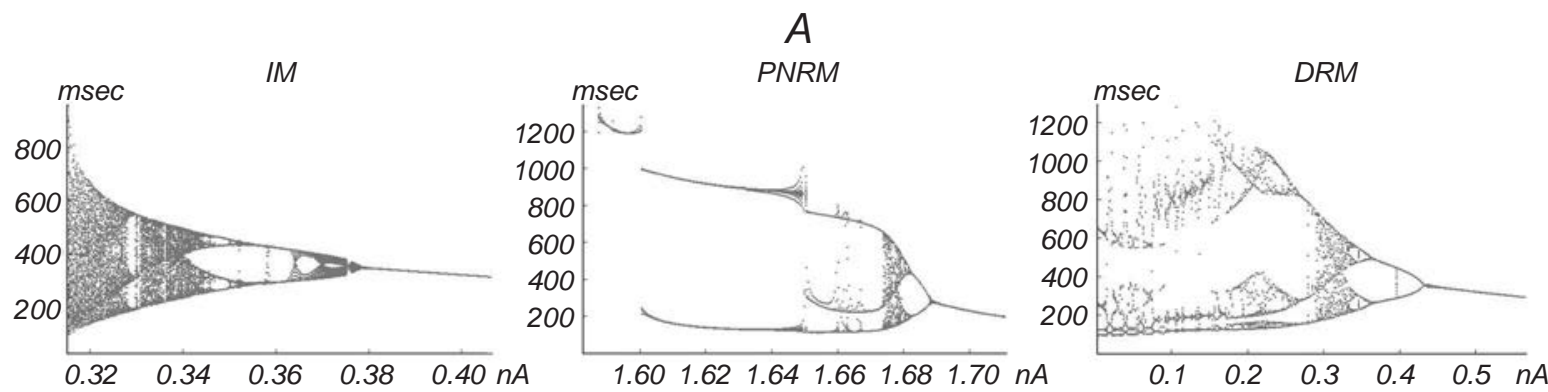

B
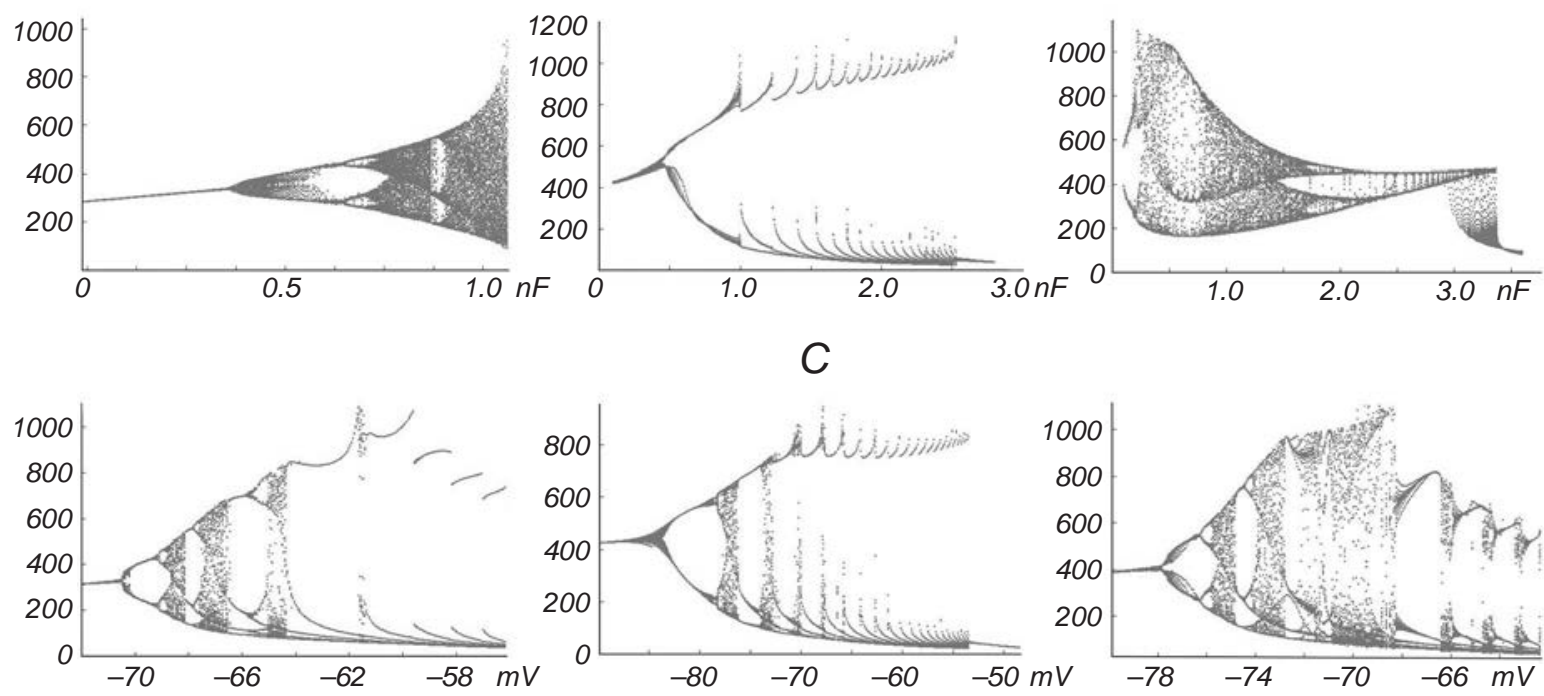

F i g. 3. ISI bifurcation diagrams plotted vs. the external current $I_{e x t}$, capacitance of the soma $C_{m, s}$, and equilibrium potential of delayed-rectifier potassium channels $E_{K d r}(\mathrm{~A}-\mathrm{C}$, respectively).

Р и с. 3. Біфуркаційні діаграми залежностей міжпікових інтервалів від $I_{e x t}, C_{m, s}$ та $E_{K d r}(\mathrm{~A}-\mathrm{C}$ відповідно). 


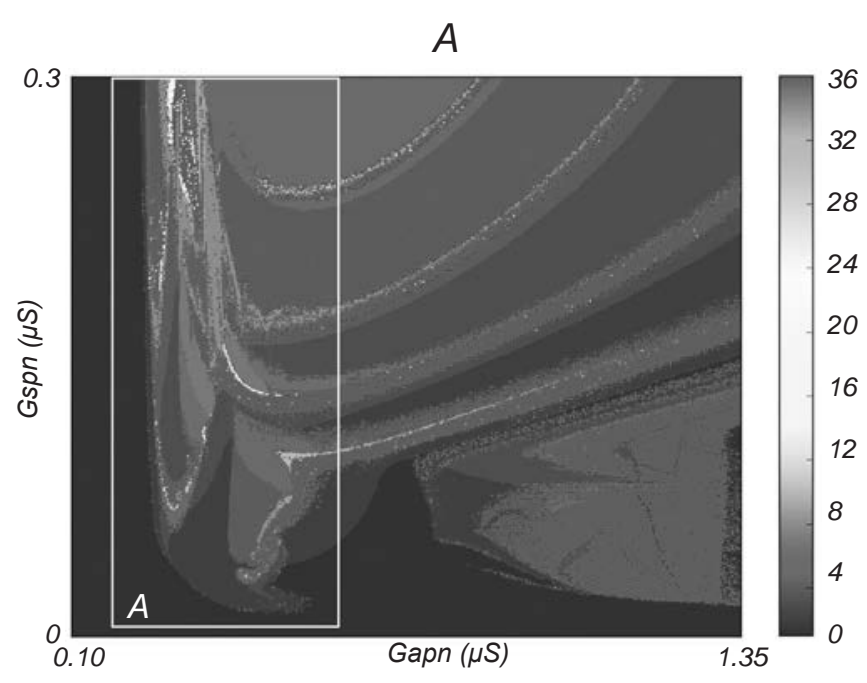

$B$

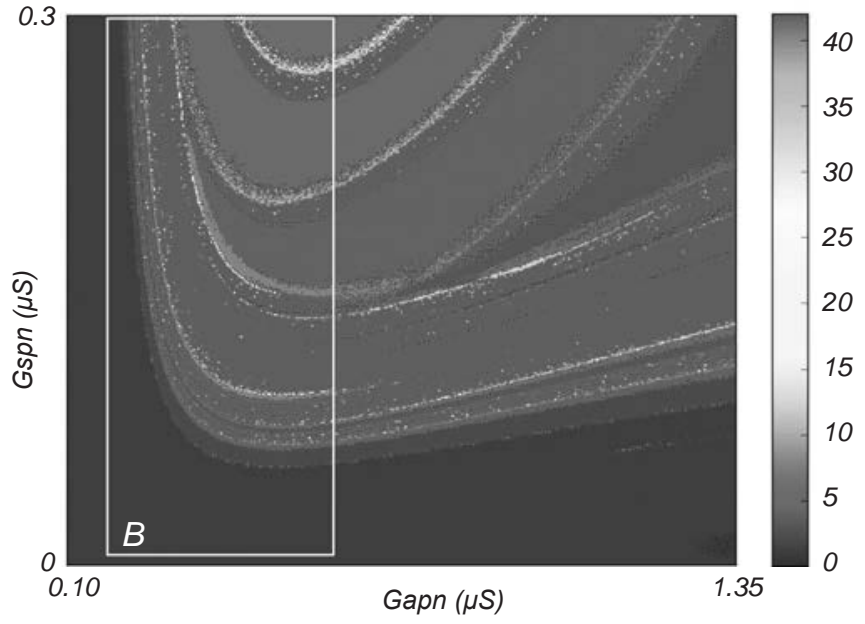

F i g. 4. Distribution of different firing patterns in two-dimensional parameter planes $\left(\mathrm{G}_{\text {apn }}, \mathrm{G}_{\mathrm{spn}}\right)$. A and B) are derived from the IM and DRM, respectively.

Р и с. 4. Розподілення різних патернів розряду на двовимірних площинах параметрів $\left(\mathrm{G}_{\mathrm{apn}}, \mathrm{G}_{\mathrm{spn}}\right)$.

not continue the bifurcating pattern but maintains the bursting firing pattern with ISIs in three periods, while the IM continues bifurcating and shows a firing mode of chaotic bursting (Fig. 3A). When $C_{m, s}$ increases, ISIs in the PNRM vary according to a period-adding bifurcation other than period-doubling bifurcation in the IM. In this process, the PNRM does not demonstrate the chaotic bursting response (Fig. 3B). In Fig. $3 \mathrm{C}$, the difference between the two diagrams is the number of bifurcations.

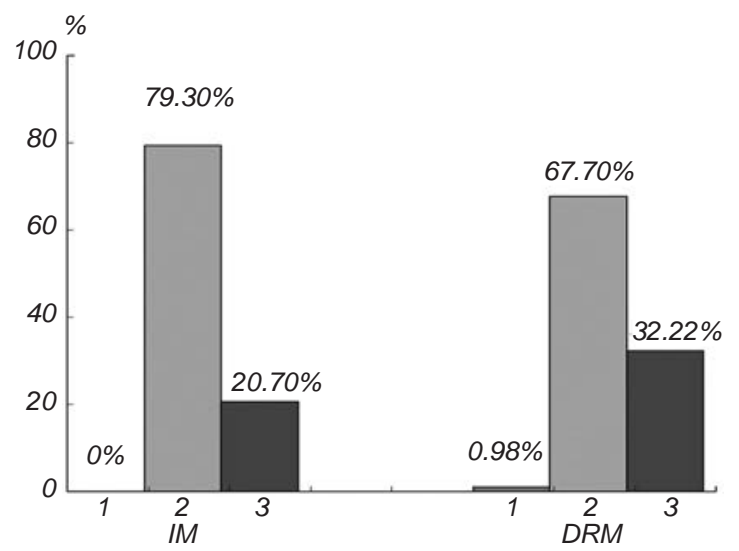

F i g. 5. Percentages of different firing patterns in the parameter planes of Fig. 4. 1-3) Columns correspond to the resting state, periodic firing, and chaotic firing, respectively.

P и с. 5. Нормовані частки різних параметрів розряду на площинах параметрів (дані рис. 4).
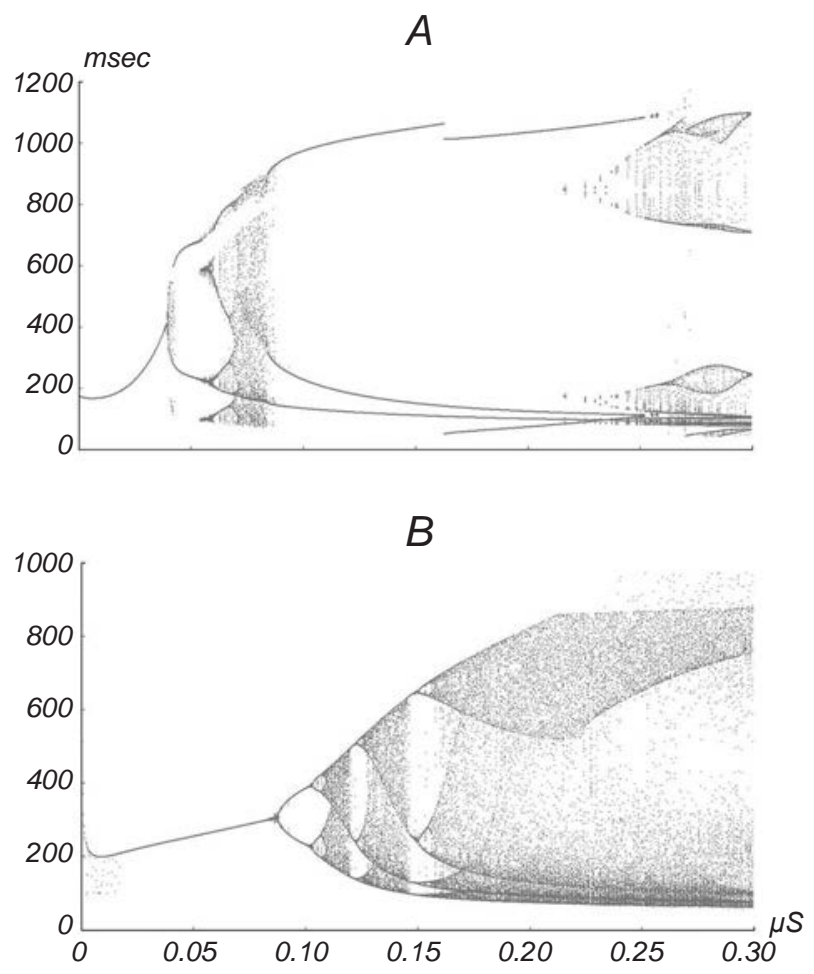

F i g. 6. Bifurcation diagrams of ISIs when $\mathrm{G}_{\mathrm{apn}}=0.2875 \mu \mathrm{S}$. A and $\mathrm{B})$ are derived from the IM and DRM respectively. Abscissa) Values of $\mathrm{G}_{\mathrm{spn}}, \mu \mathrm{S}$.

Р и с. 6. Діаграми біфуркацій міжпікових інтервалів при значенні $\mathrm{G}_{\mathrm{apn}}=0.2875$ мкСм. 
Then we focused our attention on the differences between the DRM and IM. The bifurcation modes of ISIs in these two models are also rather similar, but the DRM possesses a unique feature; this is the existence of a chaotic region. With parameter ranges $0.08 \mathrm{nA}<$ $<I_{e x t}<0.18 \mathrm{nA}($ Fig. $3 \mathrm{~A}), 3.0 \mathrm{nF}<C_{m, s}<3.5 \mathrm{nF}$ (Fig. 3B), and $-73.0 \mathrm{mV}<E_{K d r}<-68.5 \mathrm{mV}$ (Fig. 3C), such a chaotic region is present in all diagrams. These regions that appear suddenly do not follow the trend visible before, and they arrive irregularly. Once beyond these regions, the bifurcation phenomenon became normal.

Two-Dimensional Parameter-Plane Analysis. Comparison between the IM and DRM. In this section,
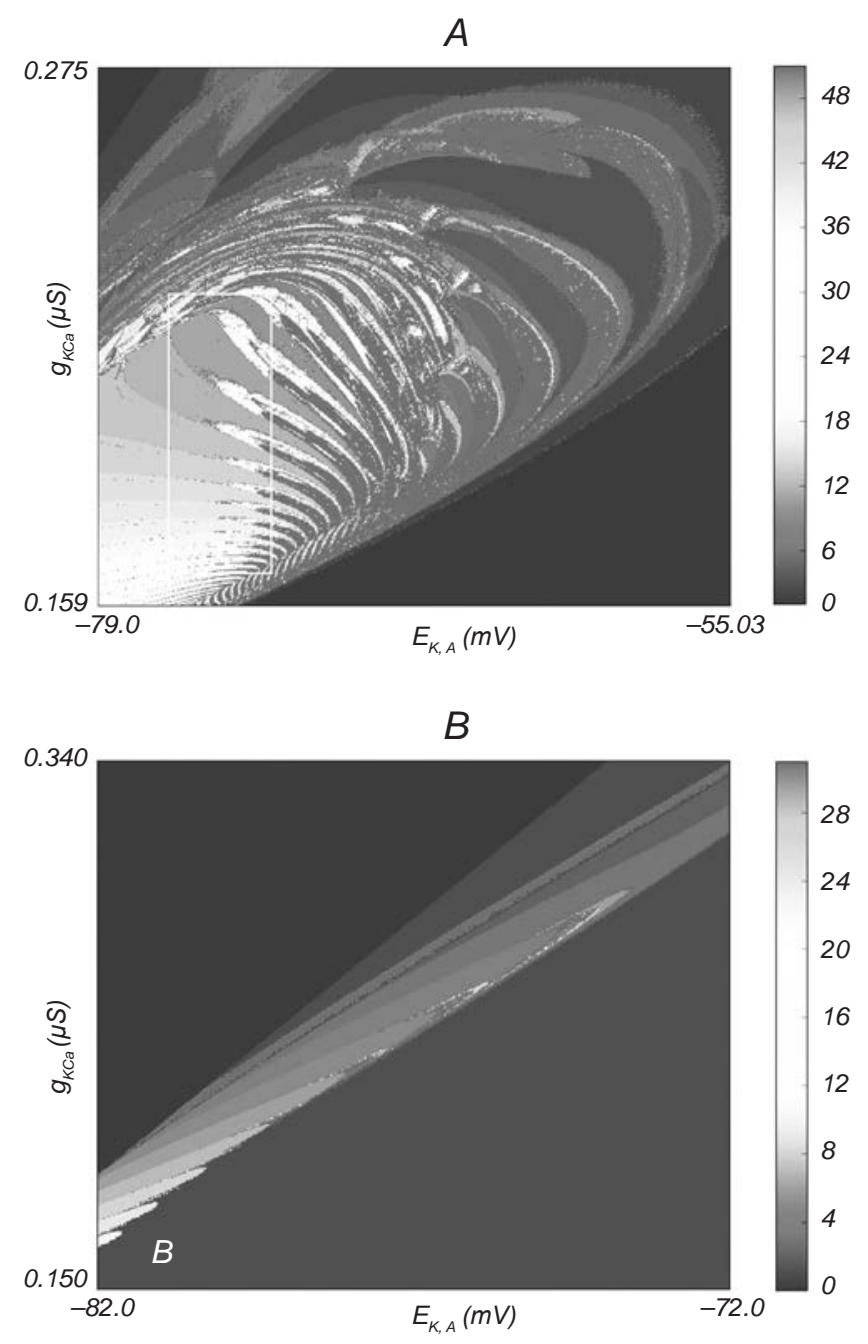

F i g. 7. Distribution of different firing patterns in two-dimensional parameter planes $\left(g_{\mathrm{KCa}}, \mathrm{E}_{\mathrm{K}, \mathrm{A}}\right)$. A and B) are derived from the IM and PNRM, respectively.

P и с. 7. Розподілення різних патернів розряду відповідно до двовимірних площин параметрів $\left(g_{\mathrm{KCa}}, \mathrm{E}_{\mathrm{K}, \mathrm{A}}\right)$. we analyze the transition of the firing patterns in a two-dimensional parameter plane plotted by a spikecounting method. As we can see in Fig. 4, these two planes are plotted on a $500 \times 500$ grid of the parameters $\left(G_{\text {apn }}, G_{\text {spn }}\right)$, which means that $25 \times 10^{4}$ simulations have been applied. In the process of simulation, the control parameter was increased from 0.1 to 1.35 in steps of $0.0025 \mu \mathrm{S}$ for the $\mathrm{G}_{\mathrm{apn}}$ or, within the interval from 0.0 to 0.3 , in steps of $0.0006 \mu \mathrm{S}$ for the $\mathrm{G}_{\mathrm{spn}}$. At each parameter step, we excluded a $10000 \mathrm{msec}-$ long segment to make sure that the system approaches a stable state. In the color bars at the right side of each diagram, zero corresponds to resting firing, the maximum of the color bar represents chaotic firing, and the other number is the period of periodic firing. In these diagrams, we can observe a number of periodic regions immersed in chaotic structures. Both Fig. 4A and Fig. 4B exhibit the comb-shaped chaotic regions, which can also be seen in some single-compartment neuron-related models, such as a Hindmarsh-Rose model and that of the pancreatic $\beta$-cell $[19,21]$. However, when comparing the A region in Fig. 4A to the $\mathrm{B}$ region in Fig. 4B, we found that some chaotic regions are converted into periodic structures after adding the dendrite compartment. The remaining chaotic regions are separated by distinct periodic structures and appear as some isolated islands. As a result, there is $11.52 \%$ less chaotic regions in the IM than those in the DRM (Fig. 5). If we fix the $\mathrm{G}_{\mathrm{apn}}$ to $0.2875 \mu \mathrm{S}$ and increase only $\mathrm{G}_{\mathrm{spn}}$ in these two models, two types of bifurcation diagrams are obtained by computing the ISIs (Fig. 6). The differences between such two-parameter planes are more obvious in these bifurcation diagrams. In Fig. 6A, the ISIs exhibit a period-doubling cascade first and then revert to chaos, turning into a wide range of periodic motions, and finally become chaotic motion via another perioddoubling cascade. It should be mentioned that only a continuous period-doubling cascade leading to chaos can be observed in the DRM.

Comparison between the IM and PNRM. Having estimated the effect of the dendrite compartment on the transition of firing patterns, we focused on the differences between the IM and PNRM. Similarly, twoparameter planes plotted by a spike-counting method $\left(g_{\mathrm{KCa}}\right.$ and $\left.\mathrm{E}_{\mathrm{K}, \mathrm{A}}\right)$ have been used to distinguish different distributions of the firing patterns (Fig. 7). Although both Fig. 7A and Fig. 7B exhibit some periodic regions immersed in chaotic structures, the variation of the firing patterns in the IM is much more compli- 


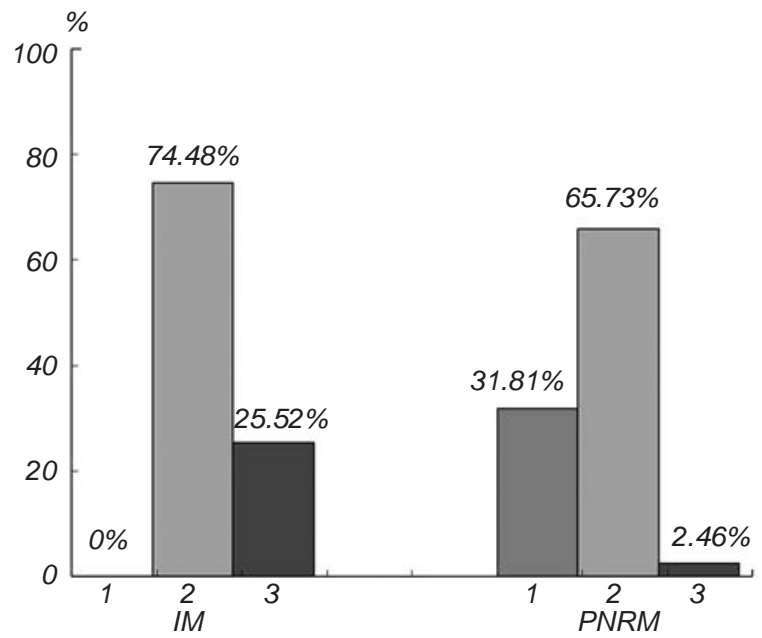

F i g. 8. Percentage of different firing patterns in the parameter planes of Fig. 7. 1-3) Columns correspond to resting, periodic, and chaotic firing, respectively.

Р и с. 8. Нормовані частки різних параметрів розряду відповідно до площин параметрів на рис. 7.
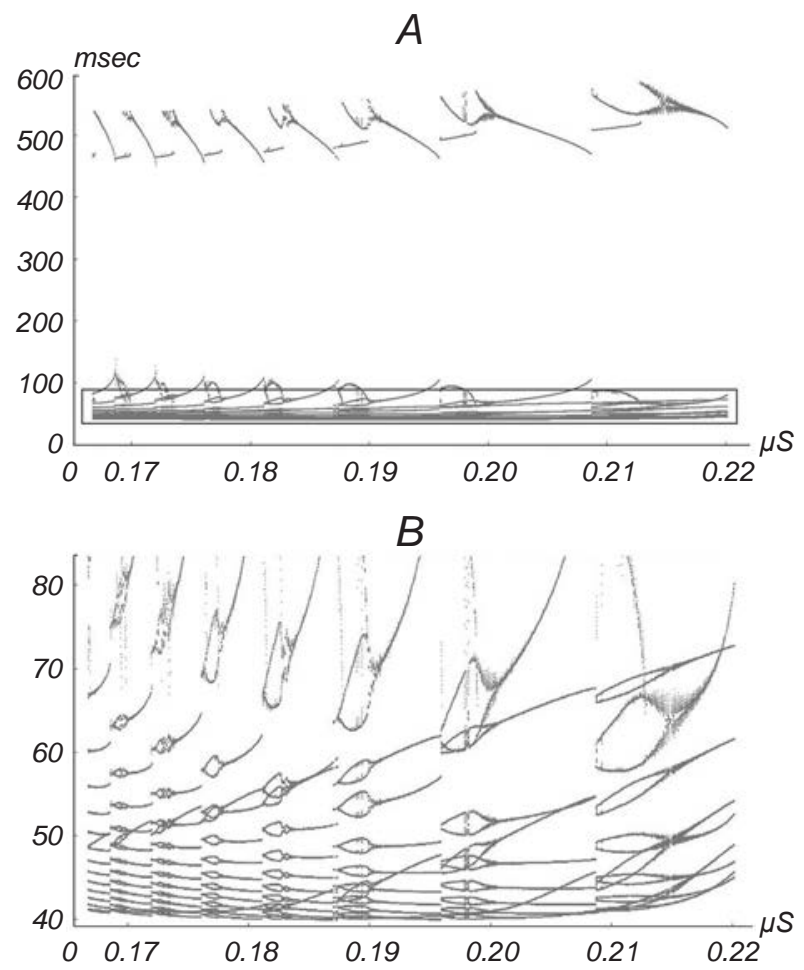

F i g. 9. Bifurcation diagram of ISIs when the point walks along the following straight line: $\mathrm{E}_{\mathrm{K}, \mathrm{A}}=-0.2227, g_{\mathrm{KCa}}-16.1579$. B) is a chart of the subregion 1 in $\mathrm{A}$.

P и с. 9. Діаграми біфуркацій міжпікових інтервалів для випадку, коли точка рухається відповідно до наступної прямої лінії: $\mathrm{E}_{\mathrm{K}, \mathrm{A}}=-0.2227, g_{\mathrm{KCa}}-16.1579$. cated. Firstly, the IM demonstrated a greater proportion of chaotic regions (Fig. 8) and possessed more "teeth" of the comb-shaped chaotic regions, dividing the plane into different periodic regions. The largest period of the periodic regions is 51 , while in the PNRM the respective value is 30 . Secondly, the region A in Fig. 7A exhibits some interesting properties of the IM that did not appear in the PNRM. The period-doubling bifurcations in this region are not accompanied by chaotic firing patterns, but they turn into other periodic firing modes. To understand how the firing patterns vary, we let the points walk along the straight line $\left(\mathrm{E}_{\mathrm{K}, \mathrm{A}}=-0.2227\right.$ and $\left.g_{\mathrm{KCa}}-16.1579\right)$ and computed the ISIs. In Fig. 9, we find that the transition pattern of ISIs within this region demonstrates a ring-shaped mode. As the $g_{\mathrm{KC}}$ decreases from 0.220 to $0.167 \mu \mathrm{S}$, the ISIs firstly exhibit a period-doubling bifurcation, and then an inverse period-doubling bifurcation is induced, thus forming a ring. In this process, period-doubling bifurcations do not induce a chaotic pattern. The periods of region A from up to down are organized as $10 \rightarrow 20 \rightarrow 11 \rightarrow 22 \rightarrow 12 \rightarrow 24 \rightarrow 13 \rightarrow 26 \rightarrow$ $\rightarrow 14 \rightarrow 28 \rightarrow 15 \rightarrow 30 \rightarrow 16 \rightarrow 32$, i.e., this sequence is of the form $\ldots \rightarrow \mathrm{n} \rightarrow 2 \mathrm{n} \rightarrow \mathrm{n}+1 \rightarrow 2(\mathrm{n}+1) \rightarrow \mathrm{n}+2 \rightarrow 2(\mathrm{n}+2)$ ... This kind of transition pattern is rather different from the patterns in Fig. 4 and does not appear in the PNRM.

\section{DISCUSSION}

Based on the SGG pacemaker neuron model, we constructed three reduced models of such a neuron. In these three models, the dendrite, axon, and primary neurite were removed from the original model, respectively. By comparing firing patterns and bifurcation modes between reduced models and the original model, we could gain an insight into the effect of compartment variation on the firing patterns.

Except for the ARM, the other two derived models could produce firing patterns rather similar to that produced by the IM, including tonic spiking, bursting, and chaotic bursting. The dynamic response of the ARM tended to be resting, no matter how intense the external stimulus was. This implies that the axon corresponds to the origin of the action potential. In the absence of the axon, the basic firing could not be obtained. Actually, this is reasonable for us to believe that this inference for the ion channels in the axon is the same as that in the Hodgkin-Huxley 
model, although the parameters of these channels are not exactly the same [22]. The PRC of the other two reduced models is of a bilinear type, while the IM has six kinds of PRC obtained by varying the synaptic conductance and duration [15]. The reason why reduced models are not sensitive to values of the synaptic conductance and duration of action of a synaptic input needs to be further studied.

The effect of the dendrites and primary neurite on varying the firing patterns was characterized by contrasting two-dimensional parameter planes between the IM and derived models, which displays the distribution of the firing patterns. In the absence of the dendrites, there are about $11.52 \%$ of periodic regions turning into chaotic regions; this indicates that the dendrite compartment can tune the system into a periodic state at some parameter ranges. On the other hand, the model that includes the primary neurite compartment demonstrates much more complicated periodic and chaotic structures in the $\left(g_{\mathrm{KCa}}\right.$ and $\left.\mathrm{E}_{\mathrm{K}, \mathrm{A}}\right)$ plane. In particular, a ring-shaped period-doubling transition mode of firing patterns has been found.

This study was not associated with any experiments on animals or tests involving human subjects; in view of this, confirmation of the correspondence of the study to existing ethical standards in this respect is not required.

The authors, W. J. Ye and Sh. Q. Liu, confirm that there were no conflicts of any kind relating to commercial or financial relations, relations with organizations or persons, which could in any way be associated with the investigation, and with the relationship of the co-authors of the article.

\section{B. $\breve{\epsilon^{l}}$, M. Лю}

\section{РОЛЬ КОМПАРТМЕНТІВ У ВИЗНАЧЕННІ}

РІЗНИХ ПАТЕРНІВ РОЗРЯДІВ, ГЕНЕРОВАНИХ РЕДУКОВАНИМИ МОДЕЛЯМИ ПЕЙСМЕКЕРІВ СТОМАТОГАСТРИЧНОГО ГАНГЛІЮ РАКОПОДІБНИХ

\author{
${ }^{1}$ Південнокитайський технологічний університет, \\ Гуангчжоу (Китай). \\ P е $з$ ю м е
}

Ендогенні компоненти центральних генераторів патернів (ЦГП), відповідальні за контроль певних стандартних моторних феноменів в організмі, генерують ритмічні групи розрядів. Базуючись на ядерній моделі пейсмекерів у стоматогастричному ганглії (СГГ) ракоподібних, ми сконструювали три редуковані моделі - модель з редукованими дендритами (ДРМ), модель 3 редукованим аксоном (АРМ) та модель з редукованим первинним нейритом (ПНРМ). У двох моделях, за виключенням АРМ, спостерігались однакові патерни розрядів. Змини різних параметрів моделей призводили до появи біфуркаційних феноменів у послідовностях міжімпульсних інтервалів, що віддзеркалювалось у варіаціях патернів розрядів. У перебігу порівняння двовимірних площин параметрів, отриманих для різних моделей, вдалось ідентифікувати впливи компартментів на варіацію параметрів розрядів. Зокрема, було встановлено специфічний вид перехідного режиму подвоєння періоду в патернах, варіації якого мали кільцеподібний характер.

\section{REFERENCES}

1. R. Nargeot, D. A. Baxter, and J. H. Byrne, "Contingentdependent enhancement of rhythmic motor patterns: an in vitro analog of operant conditioning," J. Neurosci., 17, 8093-8105 (1997).

2. R. Nargeot, C. Petrissans, and J. Simmers, "Behavioral and in vitro correlates of compulsive-like food seeking induced by operant conditioning in Aplysia," J. Neurosci., 27, 8059-8070 (2007).

3. D. K. Hartline and D. F. Russell, "Endogenous burst capability in a neuron of the gastric mill pattern generator of the spiny lobster Panulirus interruptus," J. Neurobiol., 15, No. 5, 345364 (1984).

4. H. M. Pinsker, "Aplysia bursting neurons as endogenous oscillators. I. Phase-response curves for pulsed inhibitory synaptic input," J. Neurophysiol., 40, No. 3, 527-543 (1977).

5. S. Kater and C. R. S. Kaneko, "An endogenously bursting neuron in the gastropod mollusk, Helisoma trivolvis," J. Comp. Physiol., 79, No. 1, 1-14 (1972).

6. R. M. Harris-Warrick and R. E. Flamm, "Multiple mechanisms of bursting in a conditional bursting neuron," J. Neurosci., 7, No. 7, 2113-2128 (1987).

7. H. A. Lechner, D. A. Baxter, J. W. Clark, and J. H. Byrne, "Bistability and its regulation by serotonin in the endogenously bursting neuron R15 in Aplysia," J. Neurophysiol., 75, No. 2, 957-962 (1996).

8. S. K. Maran, F. H. Sielin, K. Demla, et al., "Responses of a bursting pacemaker to excitation reveal spatial segregation between bursting and spiking mechanisms," J. Comput. Neurosci., 31, No. 2, 419-440 (2011).

9. B. J. Norris, M. J. Coleman, and M. P. Nusbaum, "Pyloric motor pattern modification by a newly identified projection neuron in the crab stomatogastric nervous system," $J$. Neurophysiol., 75, No.1, 97-108 (1996).

10. E. Marder and D. Bucher, "Central pattern generators and the control of rhythmic movements," Current Biol., 11, No. 23, R986-R996 (2001).

11. R. M. Harris-Warrick and R. E. Flamm, "Multiple mechanisms of bursting in a conditional bursting neuron," J. Neurosci., 7, No. 7, 2113-2128 (1987).

12. J. Golowasch, L. F. Abbott, and E. Marder, "Activitydependent regulation of potassium currents in an identified neuron of the stomatogastric ganglion of the crab Cancer borealis," J. Neurosci., 19, No. 20, RC33 (1999).

13. J. Golowasch, F. Buchholtz, I. R. Epstein, and E. Marder, "Contribution of individual ionic currents to activity of a 
model stomatogastric ganglion neuron," J. Neurophysiol., 67, No. 2, 341-349 (1992).

14. A. A. Prinz, V. Thirumalai, and E. Marder, "The functional consequences of changes in the strength and duration of synaptic inputs to oscillatory neurons," J. Neurosci., 23, No. 3, 943-954 (2003).

15. S. K. Maran, F. H. Sieling, K. Demla, et al., "Responses of a bursting pacemaker to excitation reveal spatial segregation between bursting and spiking mechanisms," J. Comput. Neurosci., 31, No. 2, 419-440 (2011).

16. L. Li, H. Gu, M. Yang, et al., "A series of bifurcation scenarios in the firing pattern transitions in an experimental neural pacemaker," Int. J. Bifurcat. Chaos, 14, No. 5, 1813-1817 (2004).

17. Q. Lu, H. Gu, Z. Yang, et al., "Dynamics of firing patterns, synchronization and resonances in neuronal electrical activities: experiments and analysis," Acta Mech. Sin., 24, No. 6, 593-628 (2008).
18. H. Gu, "Biological experimental observations of an unnoticed chaos as simulated by the Hindmarsh-Rose model," PloS One, 8, No. 12, e81759 (2013).

19. R. Barrio and A. Shilnikov, "Parameter-sweeping techniques for temporal dynamics of neuronal systems: case study of Hindmarsh-Rose model," J. Math. Neurosci., 1, No. 1, 1-22 (2011).

20. I. Samengo and M. A. Montemurro, "Conversion of phase information into a spike-count code by bursting neurons," PloS One, 5, No. 3, e9669 (2010).

21. E. Mosekilde, B. Lading, S. Yanchuk, et al., "Bifurcation structure of a model of bursting pancreatic cells," Biosystems, 63, Nos. 1/3, 3-13 (2010).

22. A. L. Hodgkin and A. F. Huxley, "A quantitative description of membrane current and its application to conduction and excitation in nerve," J. Physiol., 117, No. 4, 500-544 (1952). 